\title{
Arbuscular Mycorrhizal Fungi and Glomalin - Super Glue
}

\author{
M. Gomathy ${ }^{1 *}$, K.G. Sabarinathan ${ }^{1}$, T. Sivasankari Devi ${ }^{2}$ and P. Pandiyarajan ${ }^{3}$ \\ ${ }^{1}$ Agricultural College and Research Institute, Killikulam, Tuticorin District, India \\ ${ }^{2}$ Agricultural College and Research Institute, Madurai, India \\ ${ }^{3}$ Anbil Dharmalingam Agricultural College and Research Institute, Trichy, India \\ *Corresponding author
}

\section{A B S T R A C T}

\section{Keywords \\ Arbuscular mycorrhizal fungi (AM fungi), Glomalin \\ Article Info \\ Accepted: \\ 20 June 2018 \\ Available Online: \\ 10 July 2018}

Glomalin is a glycoprotein copiously present in the hyphae of AM fungi. It acts like a super glue which aggregates the soil and reduces the soil erosion. It is doing a great role in sequestration of carbon. It also sequesters heavy metals through various mechanisms. Glomalin persists in the soil for a very long time and tolerates higher temperature. It is highly recalcitrant in nature which makes them difficult to analyze biochemically. Further research is needed in this area, to tap much informations regarding the glycoprotein glomalin.

\section{Introduction}

Arbuscular mycorrhizal fungi (AM fungi) are numerously present in the soil and roots. Their association to the plants is one of the well known symbioses in the earth that links the root and soil (Koide and Mosse, 2004) and it was found to be the very old and most abundant plant microbe interaction (Smith and Read, 1997). Most of the plants in our ecosystem is colonized by AM fungi except some of the families like Brassicaceae, Amaranthaceae, Chenopodiaceae, etc (Tester and Smith, 2011). Hyphae of the AM fungi can grow several centimetres beyond the root exploration zone (Subramanian and Charest,
1999) and form a framework to hold the soil particles together by the production of glycoprotenacious substance called glomalin. AM fungi are the only producers of glomalin. AM fungi use the carbon from plants to grow and produce glomalin and in turn the plant is provided with phosphorus, other nutrients and water through the pipes called hyphae (Nichols, 2012).

\section{Glomalin}

AM fungi harbours huge quantities of glycoprotein in the hyphae and spores called glomalin. This glycoprotein was first discovered in 1996 by a woman scientist Sara 
F.Wright at the USDA Agricultural Research service (Wright et al., 1996). The name glomalin originates from the order glomales. Glomalin protein was released into the soil by AM fungal hyphae and it was present on extramatrical hyphae of all AMF tested to date (i.e. representatives from all known genera, except Sclerosystis) (Wright et al., 1996). Glomalin was observed in the surface of the spores and spore walls also (Driver et al., 2005). Many reports stated that glomalin is present outside the hyphae and it becomes sealed with glomalin enabling them to carry water and nutrients to the plant. The sheath like protection offered by glomalin to the hyphae of AM fungi gives rigidity as they have to move in the air spaces and survive inside the soil particles (Wright, 2002).

\section{Occurrence of glomalin}

The presence of glomalin is abundant and it is present in the soils and acts like glue. This glue acts in aggregation of soil and water stability. Due to the stabilized soil aggregates, carbonaceous compounds get protected from degradation and reside inside the aggregate. So the increased production of this protein glomalin ultimately results in carbon sequestration. Its concentration in soil is governed by the management practices in the agro ecosystems and it is present in wide range of soil environments like acidic, calcareous, grassland and cropland (Wright and Upadhyaya, 1998; Wright et al., 1999). Presence of glomalin has also been noted in agricultural, forest, desert, and non-cultivated soils (Wright and Upadhyaya 1996; Rillig et al., 2003; Nichols and Wright, 2004; Bai et al., 2009). This glycoprotein is found even in flood plain soils, river water and river foam (Harner et al., 2004)

Two possible mechanisms were noted in which glomalin was secreted in to the soil. One through secretion into the physical medium or the environment in which the AM fungi is present and the other through incorporation into the hyphal wall and further release of glomalin from the structural component (Wright and Upadhyaya, 1998). Occurrence of glomalin differs with various farming practices. Constant level of glomalin is maintained in the soil when the soil was less disturbed or tillage was not given, growing cover crops, using low level of fertilizers and not rotating with non mycorrhizal crops (Wright, 2002). Wright in her continuous study period of four years at Agricultural research centre she found glomalin level get increased year after year where there was no till and no prior ploughing before sowing.

Glomalin was copiously produced by the hyphae of AM fungi which was present on extramatrical hyphae of all AMF tested to date (i.e. representatives from all known genera, except Sclerosystis) (Wright et al., 1996). $\mathrm{AMF}$ has secreted glomalin into the soil by two possible mechanisms one by secretion in to the physical medium or environment and the other by incorporation into the hyphal wall and subsequent release from this structural component. Glomalin has been detected in numerous soils in large amounts (Wright and Upadhyaya, 1998). The molecule contained tightly bound iron and did not contain phenolic compounds such as tannins (Rillig et al., 2001). As hyphae degrade, this hydrophobic, highly stable glycoprotein sloughed off to coat organic matter and other soil particles. Wright et al., (1996) hypothecated that glomalin forms a conglomeration with root fragments and organic matter, thus protecting it from degradation by microorganisms. By performing carbon dating and using ${ }^{14} \mathrm{C}$ data, Rillig et al., (1999) reported that glomalin takes 7-42 years to degrade biologically. The highest levels of glomalin were found in volcanic soils of Hawaii and Japan. Lovelock et al., (2004) found that forest soils having 
sand cores, also known to have glomalin produced by AM fungal hyphae.

\section{Composition of glomalin}

Glomalin is a protenacious substance produced extracellularly by the AM fungi. It is highly persistent in nature and found to be non water soluble. It sloughs out from the hyphae and remains in the soil for very long time even after hyphal death (Driver et al., 2005). It coats the organic matter and other soil particles that forms a conglomeration with root bits, preventing from degradation by soil microorganisms and other biota in soil. Though the glomalin is not biochemically defined Schindler et al., 2007 stated that it contains 3 to $5 \% \mathrm{~N}, 36$ to $59 \% \mathrm{C}, 4$ to $6 \%$ hydrogen, 33 to $49 \%$ oxygen, and 0.03 to 0.1 $\% \mathrm{P}$. The reddish colour of glomalin extracts are due to the iron content which contributes 0.8 to $8.8 \%$ (Wright and Upadhyaya, 1998).

\section{Carbon sequestration and glomalin}

Carbon sequestration is an important aspect in reducing the atmospheric carbon to overcome the global warming. Glomalin contributes 27 percentage of carbon to be sequestered in the soil which is an important component of soil organic matter. Among the carbon stored in the soil, glomalin contributes more than humic acid (8 per cent of carbon) and weighs 2-24 times more than humic acid (Nichols et al., 2002). Glomalin related soil protein (GRSP) and its contribution to soil organic carbon is dependent upon the depth of soil and the characteristics and qualities of glomalin that is strongly influenced by soil properties and variation in the climate (Wang et al., 2017).

Glomalin stores 30-40 per cent of carbon as its protein and carbohydrates. It also forms clumps in the soil and prevents the escape of carbon from the soil (Nicholas, 2002). It also contains 1 to 9 percent tightly bound iron did not contain phenolic compounds such as tannins (Rillig et al., 2001). As hyphae degrade, this hydrophobic, highly stable glycoprotein sloughed off to coat organic matter and other soil particles. Wright et al., (1996) hypothecated that glomalin forms a conglomeration with root fragments and organic matter, thus protecting it from degradation by microorganisms. They also attaches themselves with the soil minerals such as sand silt and clay that forms clumps stable enough to resist water and wind erosion.

Wright et al., (2002) showed that higher level of carbon in the atmosphere automatically increases the amount of glomalin produced by the AM hyphae. Not only the level of glomalin, but also good soil agricultural practises tends to increase the glomalin content in the soil. AM fungi had an influential positive effect on soil organic carbon accumulation and reports revealed that extra radical mycelium of AM fungi along with its storage organs accounted for 15 percent soil organic carbon (Zhang et al., 2017).

\section{Heavy metal sequestration and glomalin}

Heavy metal is the general term which strictly refers to metals and metalloids with a specific mass higher than $5 \mathrm{~g} \mathrm{~cm}^{-3}$ (Baker, 1987). Soil is contaminated with various heavy metals from many industries like tanning, textile, and other types. The bioavailability of heavy metals in the soil is mainly based on the speciation and the soil components (Boruvka and Drabek, 2004). The cell wall of AM fungi has many cations which bind with the toxic metals like $\mathrm{Cu}, \mathrm{Pb}, \mathrm{Cd}$ and $\mathrm{Cr}$ (Kapoor and Viraraghavan, 1995). Glomalin protein released by the AM fungi has the ability to sequester the metals in their cell wall. Glomalin and AM fungi sequester the metals and make the soil a metal free environment due to the various mechanisms (Gomathy et al., 2018). It immobilizes the metals and render the plant to grow in a unpolluted soil 
(Wright and Upadhyaya, 1996). Due to the presence of glomalin the bioavailability becomes less (Gonzalez-Chavez et al., 2004). Joner et al., (2000) studied many species of AM fungi for glomalin production. Biostabilization is an important mechanism in the sequestration of heavy metals in the polluted soil (Khan, 2005). G. intraradicesinfected $\mathrm{Ri}$ T-DNA carrot roots were observed with glomalin content released from the hyphae and in the spore wall (Driver et al., 2005). Mycorrhizoremediation is one of the key factor for remediating the polluted sites that is nothing but using mycorrhizal plants for the phytoremediation of metalcontaminated soils (Gomathy et al., 2011).

\section{Properties and functions of glomalin}

Among the soil components glomalin is unique in nature.

It is highly stable in the soil and actively secreted from the hyphal tip.

It last for a very long time compared to other proteins which get degraded quickly by microbes in the soil.

Glomalin denatures when the soil has higher temperature and when it has low moisture content in the soil.

It is very persistent and tolerates higher amount of heat where most of the proteins denature.

Very tough and highly resistant to decay.

Main reservoir of soil carbon and nitrogen storage.

Reduces soil and water erosion.

Improves the infiltration and root penetration by reducing the compactness of soil.

Increases water retention and nutrient availability in the soil.

\section{References}

Bai C, He X, Tang H, Shan B, Zhao L (2009) Spatial distribution of arbuscular mycorrhizal fungi, glomalin and soil enzymes under the canopy of
Astragalus adsurgens Pall. in the Mu Us sandland, China. Soil Biol Biochem 41:941-947

Baker, AJM (1987) Metal tolerance. New Phytol., 106:93-111

Boruvka, L, Drabek O (2004) Heavy metal distribution between fractions of humic substances in heavy polluted soils. Plant Soil Environ 50:339-345

Driver, J.D., W.E. Holben, M.C. Rilling. 2005. Characterization of glomalin as a hyphal wall component of Arbuscular mycorrhizal fungi. Soil Biol. Biochem., 37(1): 101-106.

Gomathy M, K.G. Sabarinathan, M.Thangaraju and K.S. Subramanian, T.Sivashankari Devi and K. Ananthi 2011. The effect of mycorrhizae inoculated maize root exudates in alleviation of chromium toxicity in chromium polluted environments. Insight Micro 1(2):20-30 Gomathy, M, K.G. Sabarinathan and P. Pandiyarajan. 2018. Prospects of Arbuscular mycorrhizal fungi for heavy metal polluted soil. In: Microorganisms for green revolution. Pp. 91-115.

Harner, MJ, P.W Ramsey and Rillig, M.C. 2004 Protein accumulation and distribution in floodplain soils and river foam. Ecol Lett 7:829-836

Joner EJ, C. Leyval and Briones, R. 2000 Metal binding capacity of arbuscular mycorrhizal mycelium. Plant Soil 226:227-234

Kapoor A, and Viraraghavan T. 1995. Fungal biosorption an alternative treatment option for heavy metal bearing wastewater: a review. Bioresour Technol 53(3):195-206

Khan, A.G. 2005. Role of soil microbes in the rhizospheres of plants growing on trace metal contaminated soils in phytoremediation. J Trace Elem Med Biol., 18(4):355-364

Lovelock, C.E., S.F. Wright, and K.A. Nichols. 2004. Using glomalin as an indicator for arbuscular mycorrhizal hyphal growth: an example from a tropical rainforest soil. Soil Biol. Biochem. 36: 1009-1012. 
Mark, T and Smith, F. 2011. The phenomenon of "nonmycorrhizal" plants. Canadian Journal of Botany 420-431.

Nichols, A.K, 2002. Glomalin- Hiding place for a third of the world's storage carbon. Agricultural Research. 4-9.

Nichols, K.A. and S.F. Wright. 2006. Carbon and nitrogen in operationally-defined soil organic matter pools. Biol. Fertil. Soils. 43: 215-220.

Rillig, M.C., P.W. Ramsey, S. Morris, and E.A. Paul. 2003. Glomalin, an arbuscularmycorrhizal fungal soil protein, responds to land-use change. Plant Soil. 253: 293-299.

Rillig, M.C., S.F. Wright, K.A. Nichols, W.F. Schmidt, M.S. Torn. 2001. Large contribution of arbuscular mycorrhizal fungi to soil carbon pools in tropical forest soils. Plant Soil. 233: 167-177.

Rillig, M.C., S.F. Wright, M.F. Allen, and C.B. Field. 1999. Rise in carbon dioxide changes soil structure. Nature 400: 628.

Smith, S.E. and D.J. Read. 1997. In: Mycorrhizal Symbiosis, second ed. Academic press, London, p.589.

Subramanian, K.S and C. Charest. 1997. Nutritional, growth and reproductive responses of maize (Zea mays L) to arbuscular mycorrhizal inoculation during and after drought stress, Scientia Hor., 107:245-253.

Wang,W, Z. Zhong, W. Wang, Y. Fu, and X. He, 2017. Glomalin contributed more to carbon, nutrients in deeper soils, and differently associated with climates and soil properties in vertical profiles.
Scientific Reports 7: 13003

Wright, S.F, M. Franke-Synder, J.B. Morton and Upadhyaya A. 1996. Time course study and partial characterization of a protein on hyphae of arbuscular mycorrhizal fungi during active colonization of roots. Plant Soil: 181:193-203

Wright SF, Starr JL, Paltineanu IC (1999) Changes in aggregate stability and concentration of glomalin during tillage management transition. Soil Sci Soc Am J 63:1825-1829

Wright SF, Upadhyaya A (1998) A survey of soils for aggregate stability and glomalin, a glycoprotein produced by hyphae of arbuscular mycorrhizal fungi. Plant Soil 198:97-107

Wright, S.F. and R.L. Anderson. 2000. Aggregate stability and glomalin in alternative crop rotations for the central Great Plains. Biol. Fertil. Soils 31: 249253.

Wright, S.F., M. Franke-Snyder, J.B. Morton, and A. Upadhyaya. 1996. Time-course study and partial characterization of a protein on hyphae of arbuscular mycorrhizal fungi during active colonization of roots. Plant Soil 181: 193-203.

Zhang, J, Tang, X, Zhong, S, Yin G, Gao, Y and $\mathrm{He}, \mathrm{X} .2017$. Recalcitrant carbon components in glomalin-related soil protein facilitate soil organic carbon preservation in tropical forests. Scientific Reports 7: 2391.

\section{How to cite this article:}

Gomathy, M., K.G. Sabarinathan, T. Sivasankari Devi and Pandiyarajan, P. 2018. Arbuscular Mycorrhizal Fungi and Glomalin - Super Glue. Int.J.Curr.Microbiol.App.Sci. 7(07): 28532857. doi: https://doi.org/10.20546/ijcmas.2018.707.334 